\title{
Characterization of Sludge Produced by Treatment of Water from the Ribaa and Bittit Karstic Springs (Meknes, Morocco)
}

\author{
Nabila Basri' ${ }^{1}$, Mohamed Farhaoui ${ }^{2}$, Lamyae Talbi ${ }^{1,2}$, Mustapha Derraz $^{1 *}$, Hammou Ahlafi $^{3}$ \\ ${ }^{1}$ Biology Department, Faculty of Sciences, My Ismail University, Meknes, Morocco \\ ${ }^{2}$ National Office of Electricity and Drinking Water, Meknes, Morocco \\ ${ }^{3}$ Chimestry Department, Faculty of Sciences, My Ismail University, Meknes, Morocco \\ Email: ^mderraz@ymail.com
}

How to cite this paper: Basri, N., Farhaoui, M., Talbi, L., Derraz, M. and Ahlafi, H. (2020) Characterization of Sludge Produced by Treatment of Water from the Ribaa and Bittit Karstic Springs (Meknes, Morocco). Journal of Water Resource and Protection, 12, 607-617.

https://doi.org/10.4236/jwarp.2020.127037

Received: June 17, 2020

Accepted: July 20, 2020

Published: July 23, 2020

Copyright (c) 2020 by author(s) and Scientific Research Publishing Inc. This work is licensed under the Creative Commons Attribution-NonCommercial International License (CC BY-NC 4.0). http://creativecommons.org/licenses/by-nc/4.0/

\begin{abstract}
Problem Statement: Surface Water Treatment for potable supplies typically involves coagulation, flocculation, and processes. All water treatment plants produce sludge, during the purification of raw water, according to the level of the water turbidity. The aluminum sulfate is the most common coagulant used in water treatment plants of Morocco, as well as in many countries all over the world. It is difficult to manage sludge produced by the treatment plant. However, several studies, based on a set of jar test experiments, have demonstrated that it can be used in the process to improve the quality of the treated water and reduce the aluminum sulfate dose. Approach: In this study, the raw water treated and sludge produced in water treatment plant of Meknes, Morocco are investigated for chemical and bacteriological proprieties. The texture characterization of the dried sludge produced through the process of coagulation/flocculation and that of aluminum sulfate, used as coagulant aid, are obtained by nitrogen adsorption isotherms. Results: The physical properties of the raw water indicate its high turbidity during periods of heavy rainfall in the Bittit and Ribaa springs catchment area. However, these chemical properties indicate the quality of fresh water rich in magnesium, related to the dolomitic nature of the liastic aquifer. The bacteriological analysis of sludge produced in the treatment plant, confirms the elimination of pathogenic germs by the treatment process used. As regards the texture characterization the results demonstrated that the sludge presents some similarities with the sulfate. However, a clear difference is observed between the two solids, according to the pores distribution. Conclusions/Recommendations: Taking aluminum sulfate and sludge in comparison, it is possible to use the sludge for improving the coagulation process in water treatment.
\end{abstract}




\section{Keywords}

Water Treatment, Turbidity, Sludge, Aluminum Sulfate, Texture Characterization, N2 Isotherms

\section{Introduction}

The demand for water supply is increasing over the last century, due to improved lifestyle, industrial development and population growth. Karst systems can provide considerable resources. They have a significant proportion of the water supply at the local and regional level (southeastern Europe, the Mediterranean basin, etc.). On a global scale, it is estimated that about $25 \%$ of the world's population is supplied with domestic water from karstic aquifers [1].

In Morocco, the Tabular Middle Atlas Causses reservoir is the main drinking water supply of Fez-Meknes region. However, in rainfall periods their water quality is impaired, due to a strong turbidity [2]. This phenomenon is well known in karstic springs and can make the water unfit for consumption [3]. Consequently, settling and filtration systems are required to remove the recurrent problem of turbidity [4].

Coagulation is an essential step of the treatment scheme for removing colloidal as well as suspended solids from raw water. This process could be considered as one of the most typical physicochemical processes used in water treatments, due to its easy operation, relatively simple design and low energy consumption [5]. Aluminum Sulfate (AS) or alum $\left(\mathrm{Al}_{2}\left(\mathrm{SO}_{4}\right)_{3}-18 \mathrm{H}_{2} \mathrm{O}\right)$ is the most widely used coagulant in the world for drinking water treatment [6]. The colloidal and suspended impurities present in the water are removed by charge neutralization. In fact, the coagulation process results in the production of voluminous sludge known as Water Treatment Sludge (WTS) that poses difficulty in handling and disposal to environmental engineers. A typical water treatment plant produces about 100,000 tons/year of sludge [7].

To overcome this problem, the produced sludge can in turn be used as coagulant or a coagulant aid with other synthetic and industrial coagulants, such as aluminum sulfate, in order to reduce the coagulant consumption in the water treatment plant [8]. For that, it is necessary to identify the textural characteristics of the sludge which could be adapted to the coagulation process for possible reuse.

The aim of this study is to characterize the sludge produced from natural turbid water of karstic springs, in relation to the physical and chemical properties of water treated. The texture of the dried sludge produced through the process of coagulation/flocculation and that of aluminum sulfate, used as coagulant, are also obtained by nitrogen adsorption isotherms.

\section{Study Area}

This study was developed in a wide plain (Saïs plain) of major economic interest because of intensive agriculture and the location of great cultural and touristic 
sites. All these human activities require large water resources that come from the karstic systems located in the Tabular Middle Atlas (TMA), in Morocco.

In the TMA, El Hajeb-Ifrane causse covers $852 \mathrm{~km}^{2}$ (Figure 1). Its high rainfall $(>1000 \mathrm{~mm})$ in a higher relief of the Ifrane catchment area (over $1600 \mathrm{~m}$ ), represents the water tower providing more than $50 \%$ of the recharge of the Saïs aquifer system; and giving birth to several springs, mainly the two big springs Bittit and Ribaa, located at the junction of El Hajeb-Ifrane causse and the Plain of Saïs.

\subsection{Characteristics of Bittit and Ribaa Springs}

Part of the water from Bittit $(600 \mathrm{l} / \mathrm{s})$ and all the water from the downstream Ribaa spring $(200 \mathrm{l} / \mathrm{s})$ are used to supply drinking water for the city of Meknes (about 70\%). Since the nineties (1994-95), the water of these natural outflows has suffered from occasional turbidity problems [3]. Table 1 summarizes the hydrological characteristics of Bittit and Ribaa springs in relation to the rainfall recorded in the El Hajeb-Ifrane catchment area.

According to a review of more than 25 years of observations (1975-2004), it has been noted that above $1800 \mathrm{~m}$ altitude, at Ifrane, the average number of rainy days is 100 days, including 70 to 85 days of rain and 15 to 30 days of snow [9]. It can be shown also, that during the precipitation period (from December to May), the flow rate of the Ribaa spring fluctuates sharply; however the Bittit spring is characterized by its high flow rate and regularity of the regime.

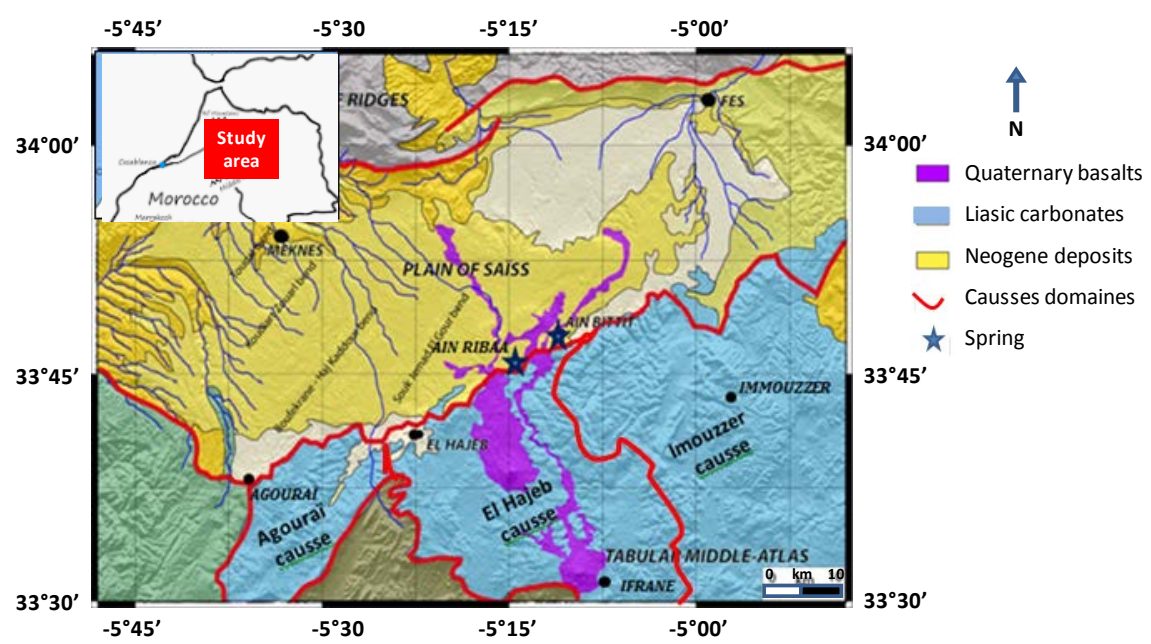

Figure 1. Simplified geological map of El Hajeb-Ifrane causse ([3], modified).

Table 1. Average monthly flows of Bittit and Ribaa springs in relation to rainfall at Bittit and Ifrane stations [9].

\begin{tabular}{|c|c|c|c|c|c|c|c|c|c|c|c|c|c|}
\hline & & Sep & Oct & Nov & Dec & Jan & Feb & Mar & Apr & Mai & Jun & Jul & Aug \\
\hline $\mathrm{P}(\mathrm{mm})$ & Bittit: 760 m & 21 & 52 & 75 & 84 & 76 & 68 & 80 & 78 & 50 & 19 & 4 & 5 \\
\hline 1935/01 & Ifrane: $930 \mathrm{~m}$ & 34 & 79 & 124 & 155 & 128 & 122 & 114 & 111 & 68 & 28 & 9 & 12 \\
\hline $\mathrm{Q}_{\text {moy }}\left(1 \cdot \mathrm{s}^{-1}\right)$ & Bittit & 1451 & 1469 & 1479 & 1481 & 1541 & 1539 & 1546 & 1595 & 1566 & 1504 & 1470 & 1479 \\
\hline $1975 / 00$ & Ribaa & 546 & 564 & 559 & 584 & 612 & 628 & 681 & 674 & 643 & 606 & 583 & 578 \\
\hline
\end{tabular}




\subsection{Turbidity Events}

Based on our previous studies of this problem [10], the turbidity of Bittit and Ribaa springs water depends on the rainfall in El Hajeb-Ifrane catchment area, mainly at the Bittit station (Figure 2). Indeed, in times of heavy rain or showers, the turbidity increases significantly. This is the case during the heavy winter rain periods (from January to March 2013 and 2014) or autumn showers (November 2014).

In the rainfall period, the turbidity of raw water from Bittit and Ribaa springs, drawn into mixing basins of the plant, increase to reach levels exceeding 900 NTU. Number of days per different turbidity levels of this water intended for treatment, are presented in Table 2.

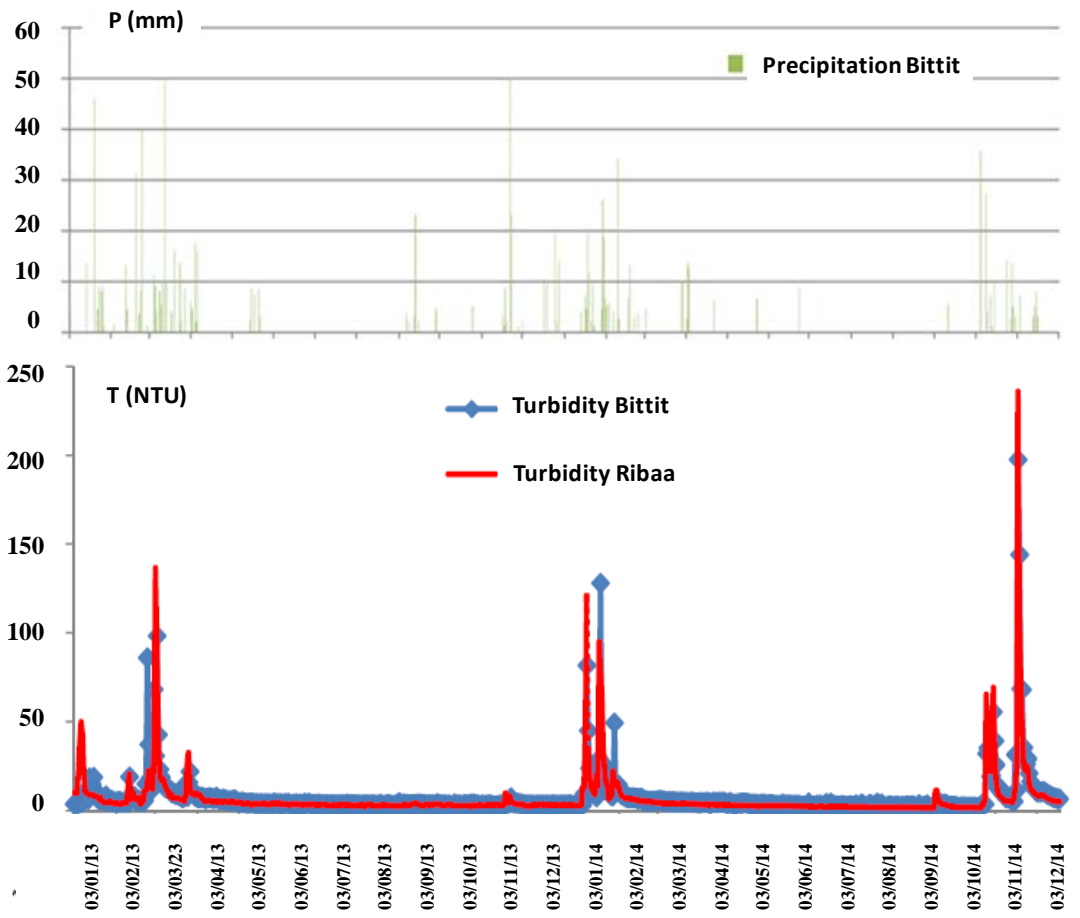

Figure 2. Rainfall intensity and water turbidity levels of Bittit and Ribaa springs from $01 / 01 / 2013$ to $31 / 12 / 2014$ [10].

Table 2. Turbidity level distribution (Low: TL, Medium: TM and High: TH) of raw water into mixing basins of WTP (from 2010 to 2014) [11].

\begin{tabular}{ccccc}
\hline \multicolumn{5}{c}{ Number of days per turbidity levels (NTU): } \\
\hline Year & $\mathrm{T}_{\mathrm{L}}<10$ & $10<\mathrm{T}_{\mathrm{M}}<20$ & $\mathrm{~T}_{\mathrm{H}}>20$ & Total \\
\hline 2010 & 0 & 113 & 252 & 365 \\
2011 & 0 & 276 & 89 & 365 \\
2012 & 301 & 55 & 10 & 366 \\
2013 & 260 & 97 & 8 & 365 \\
2014 & 247 & 94 & 24 & 365 \\
Total & $\mathbf{8 0 8}$ & $\mathbf{6 3 5}$ & $\mathbf{3 8 3}$ & $\mathbf{1 8 2 6}$ \\
$\%$ & $\mathbf{4 4 \%}$ & $\mathbf{3 5 \%}$ & $\mathbf{2 1 \%}$ & $\mathbf{1 0 0 \%}$ \\
\hline
\end{tabular}




\section{Methodology}

\subsection{Turbidity Treatment}

The Water Treatment Plant (WTP) of Meknes city is located in the middle of Morocco. This unit, as part of other water resources for Meknes city, has a nominal capacity of $600 \mathrm{l} / \mathrm{s}$ of treated water, whose source is the two springs of Bittit (60\%) and Ribaa (40\%).

At the mixing basins of WTP, located about $30 \mathrm{~km}$ from the city of Meknes, temperature, $\mathrm{pH}$, electrical conductivity and turbidity of raw water from Bittit and Ribaa springs, drawn into mixing basins of the WTP, were measured continuously, using field instruments electrodes, installed at these basins and connected to a control room, where the data is recorded and evaluated.

As a common practice, Jar test involves taking a raw water samples from mixing basins of WTP and applying different quantities of coagulant to each sample. After a short period of time, each sample is assessed for water quality and the dosage that produces the optimal result used a set point. This operation should be repeated by the operators each time when the quality of raw water changes.

\subsection{Raw Water and Sludge Analysis}

Water samples collected from these units were filtered with a $0.45 \mu \mathrm{m}$ membrane. The obtained liquid filtrate and the solid sample of dried sludge were analyzed to determine their physicochemical parameters and bacteriological properties. The chemical composition of raw water was determined by absorption atomic spectroscopy. However, bacteriological analyses are carried out by multiple tubes according to Moroccan Standards (NM 03-7-003 modified), established by the National Drinking Water Office [12].

\subsection{B.E.T. Method Analysis}

In order to compare the sludge produced by coagulation/flocculation process and aluminum sulfate used at the WTP, the texture of the two solid powders was determined by the B.E.T. (Brunuaer, Emmett and Teller) and BJH (Barrett, Joyner and Halenda) methods using a Micrometrics ASAP 2010. This method is based on the physical adsorption of $\mathrm{N} 2$ on a solid surface at the temperature of liquid nitrogen $\left(\mathrm{T}=-196^{\circ} \mathrm{C}\right)$ [13]. It allows us the measurement of the specific surface area, pore diameter and pore volume from the N2 adsorption and desorption hysteresis plots. Before any measurement, a mass of powder of sludge were degassed under primary vacuum at $150^{\circ} \mathrm{C}$ for one night in order to remove the impurities physisorbed on their surfaces.

\section{Results and Discussion}

\subsection{Turbidity Treatment}

Variations in the parameters used in the control of the water treatment process in this plant are shown in Table 3. 
Table 3. Statistical summary of raw water conditions from $01 / 01 / 2013$ to $31 / 12 / 2015$.

\begin{tabular}{cccc}
\hline Variables & & Min & Max \\
\hline Turbidity $(\mathrm{NTU})$ & Bittit file & 1.7 & 850 \\
$\mathrm{pH}$ & Ribaa file & 1.62 & 960 \\
Temperature $\left({ }^{\circ} \mathrm{C}\right)$ & & 6.80 & 7.74 \\
Conductivity $\mu \mathrm{s} \cdot \mathrm{cm}^{-1}$ & & 14 & 24 \\
\hline
\end{tabular}

The study of turbidity water removal, using the coagulant aluminum sulfate (AS) and sludge as a coagulant aid are presented in Table 4.

The sludge produced at the water treatment plant of Meknes is an additional burden for the plant managers. Their reuse as a coagulant aid with the aluminum sulfate improve not only the water quality produced by the treatment plant (turbidity removal more than $99 \%$ in high turbidity level), but also it can reduce (about 50\%) the aluminum sulfate dose used in the coagulation process [14]. Their reuse in combination with aluminum sulfate is therefore very important, in improving the quality of the water produced by the treatment plant [15]. This justifies the characterization of these two solids in the present work.

\subsection{Raw Water and Sludge Analysis}

After rainy events that generate a flow over the spring catchment area, the water quality is altered and the turbidity of the two karstic springs varies considerably. A causal link between the rainfall intensity and the occurrence of turbidity at both Bittit and Ribaa springs was noted [10]. The photos of Figure 3, taken in April 2018, illustrate this relationship.

In the mixing basins of WTP (Figure 4(a)), where aluminum sulfate coagulant was added, the coagulation-flocculation process causes a small particles to stick to one another, forming larger particles. After sedimentation and filtration the sludge produced were dehydrated and dried for storage (Figure 4(b)).

Table 5 and Table 6, shows the properties of the raw water (from Bittit and Ribaa spring) drawn into mixing basins of WTP and that of the sludge produced after treatment.

From these results, the following conclusions can be drawn:

- The average electrical conductivity of the water, generally low, can thus qualify the waters of the two springs as fresh;

- The abundance of magnesium ion is certainly related to the dolomitic nature of the liastic aquifer [8];

- The absence of pathogenic germs in the case of sludge is evidence of its elimination by the treatment process carried out in the mixing basins of WTP.

\subsection{B.E.T. Analysis}

Figure 5 shows, the hysteresis obtained by the B.E.T. method in the relative pressure (P/P0) range from 0 to 1 , for sludge (a) and aluminum sulfate (b). 
N. Basri et al.

Table 4. Turbidity removal by reuse of sludge within aluminum sulfate (AS) at different level of turbidity.

\begin{tabular}{|c|c|c|c|}
\hline & $\begin{array}{c}\text { Low } \\
\text { Turbidity }\left(\mathrm{T}_{\mathrm{L}}\right)\end{array}$ & $\begin{array}{c}\text { Medium } \\
\text { Turbidity }\left(\mathrm{T}_{\mathrm{M}}\right)\end{array}$ & $\begin{array}{c}\text { High } \\
\text { Turbidity }\left(\mathrm{T}_{\mathrm{H}}\right)\end{array}$ \\
\hline Initial turbidity & 9.34 & 21 & 39.4 \\
\hline Optimal dose of AS (mg/l) used alone & 10 & 20 & 20 \\
\hline Turbidity removal (\%) & $96.71 \%$ & $98.05 \%$ & $98.98 \%$ \\
\hline $\begin{array}{c}\text { Optimal doses of sludge }(\mathrm{mg} / \mathrm{l}) \\
\text { used within AS }\end{array}$ & 35 & 50 & 60 \\
\hline Turbidity removal (\%) & $96.71 \%$ & $98.05 \%$ & $98.98 \%$ \\
\hline $\begin{array}{l}\text { Dose of AS (mg/l) proposed to be } \\
\text { used with optimal doses of sludge }\end{array}$ & 6 & 10 & 12 \\
\hline Turbidity removal (\%) & $97.56 \%$ & $98.96 \%$ & $99.47 \%$ \\
\hline
\end{tabular}

Table 5. Physical properties of raw water, during turbidity event of 22/10/2018.

\begin{tabular}{ccccc}
\hline Parameter & \multicolumn{3}{c}{$22 / 10 / 2018$} & from 2009 to 2016 [13] \\
\hline Sampler time & $8 \mathrm{H}$ & $12 \mathrm{H}$ & $18 \mathrm{H}$ & \\
\hline $\mathrm{T}^{\circ} \mathrm{C}$ & 17.10 & 17.20 & 17 & $6.8-7.7$ \\
$\mathrm{pH}$ & 7.28 & 7.26 & 7.28 & $1.6-960$ \\
Turbidity $(\mathrm{NTU})$ & 30.10 & 27.50 & 28.6 & $509-624$ \\
\hline Conductivity $\left(\mu \mathrm{S} \cdot \mathrm{cm}^{-1}\right)$ & 600 & 600 & 599 & \\
\hline
\end{tabular}

Table 6. Chemical and bacteriological proprieties of raw water and sludge procured at WTP of Meknes.

\begin{tabular}{cccc}
\hline Parameters & Raw water & $\begin{array}{c}\text { Sludge from } \\
\text { File }(1)\end{array}$ & $\begin{array}{c}\text { Sludge from } \\
\text { File }(2)\end{array}$ \\
$\mathrm{Ca}(\mu \mathrm{g} / \mathrm{l})$ & 23 & 20 & 24 \\
$\mathrm{Cd}(\mu \mathrm{g} / \mathrm{l})$ & 20 & 10 & 16 \\
$\mathrm{Zn}(\mu \mathrm{g} / \mathrm{l})$ & 24 & 0.005 & - \\
$\mathrm{Pb}(\mu \mathrm{g} / \mathrm{l})$ & $<5 \mu \mathrm{g} / 1$ & - & 1.70 \\
$\mathrm{~K}(\mathrm{mg} / \mathrm{l})$ & 0.36 & 0.53 & 16.60 \\
$\mathrm{Mg}(\mathrm{mg} / \mathrm{l})$ & 16.32 & 16.52 & 0.04 \\
$\mathrm{Mn}(\mathrm{mg} / \mathrm{l})$ & - & 1.101 & 0.67 \\
$\mathrm{Na}(\mathrm{mg} / \mathrm{l})$ & 0.58 & 0.65 & 0 \\
$\begin{array}{c}\text { B. coliforms } \\
(\mathrm{UFC} / 100 \mathrm{ml})\end{array}$ & 75 & 0 & 0 \\
$E$. coli & 23 & 0 & 0 \\
$\begin{array}{c}\text { (UFC/100ml) } \\
\text { Ent. Intestines } \\
(\mathrm{UFC} / 100 \mathrm{ml})\end{array}$ & 23 & 0 & 0 \\
\hline & & 0 & \\
\hline
\end{tabular}



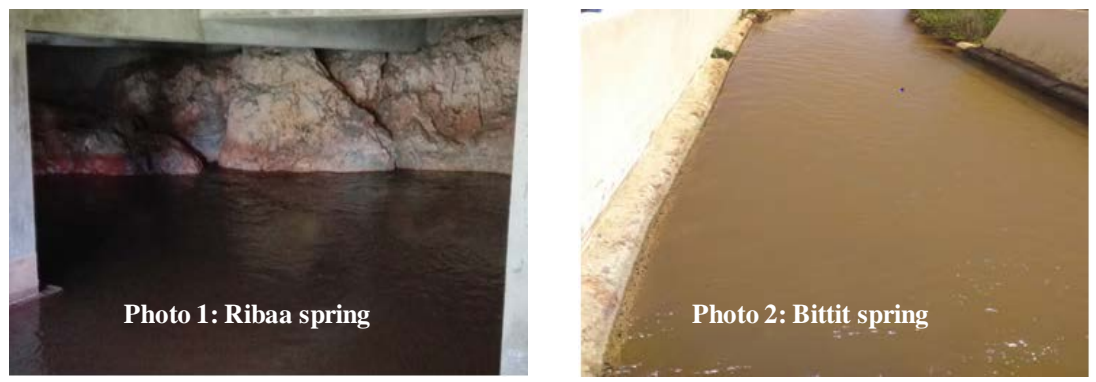

Figure 3. Occurrence of turbidity at Ribaa (Photo 1) and Bittit (Photo 2) springs (April 2018).
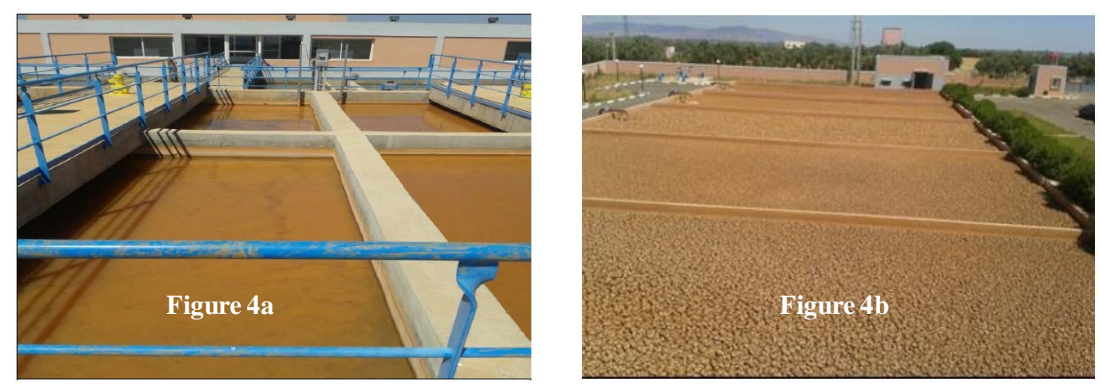

Figure 4. (a): Turbid water in the mixing basins, (b): Dried sludge basins of WTP.
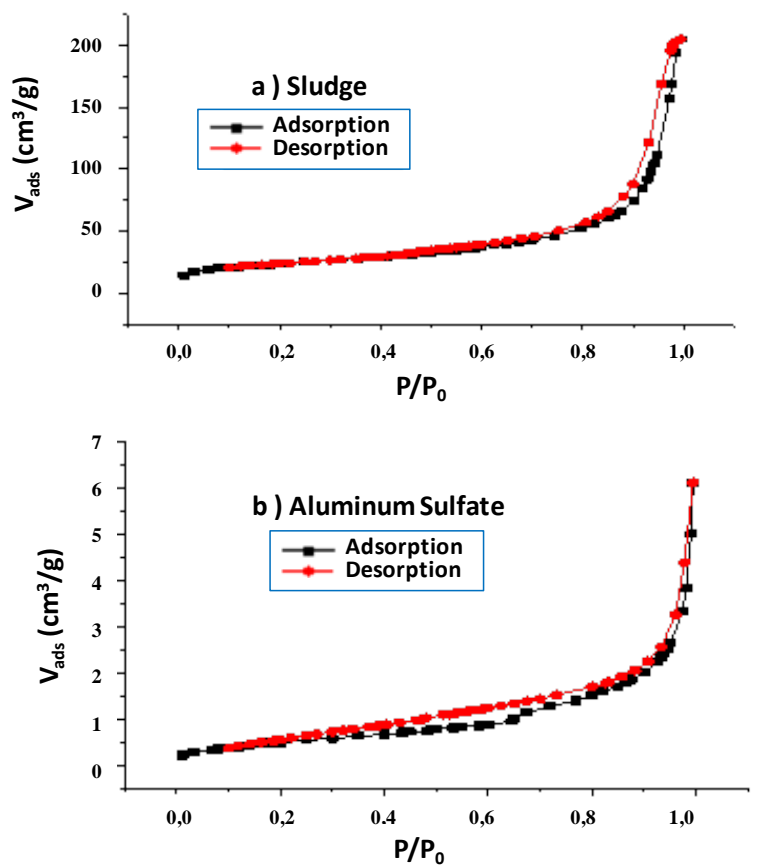

Figure 5. Adsorption-desorption isotherms of sludge (a) and aluminum sulfate (b).

The adsorption-desorption isotherm obtained in both solids sludge and aluminum sulfate demonstrates that it is a mesoporous material, as there is little increase at a relatively low pressure and a steep gas uptake at a relatively high pressure $\left(\left(\mathrm{P} / \mathrm{P}^{\circ}: 0.80-1.0\right)\right.$. These characteristics correspond to type IV isotherms according to the IUPAC (International Union of Pure and Applied 
Chemistry) classification, which are generally obtained in the case of mesoporous solids.

Pore volume distributions are obtained with sludge and aluminum sulfate (Figure 6), are another proof of their mesoporous nature. The two products exhibit the same dominant pore width centered at 37 and $40 \AA$ for sludge and aluminum sulfate, respectively. For sludge, another flat peak at about $205 \AA$ is detected by N2 sorption isotherms. No conclusion can be made for this result. However, other studies are further recommended for this last observation, such: mercury porosimetry experiments.

In Table 7 are gathered the different parameters, deduced from these isotherms. It can be seen that the sludge has a larger specific surface area than that of the aluminum sulfate $\left(81>1.7 \mathrm{~m}^{2} \cdot \mathrm{g}^{-1}\right)$. Furthermore, the volume diameters of the pores and specific surface area for the former are higher than that of the latter.
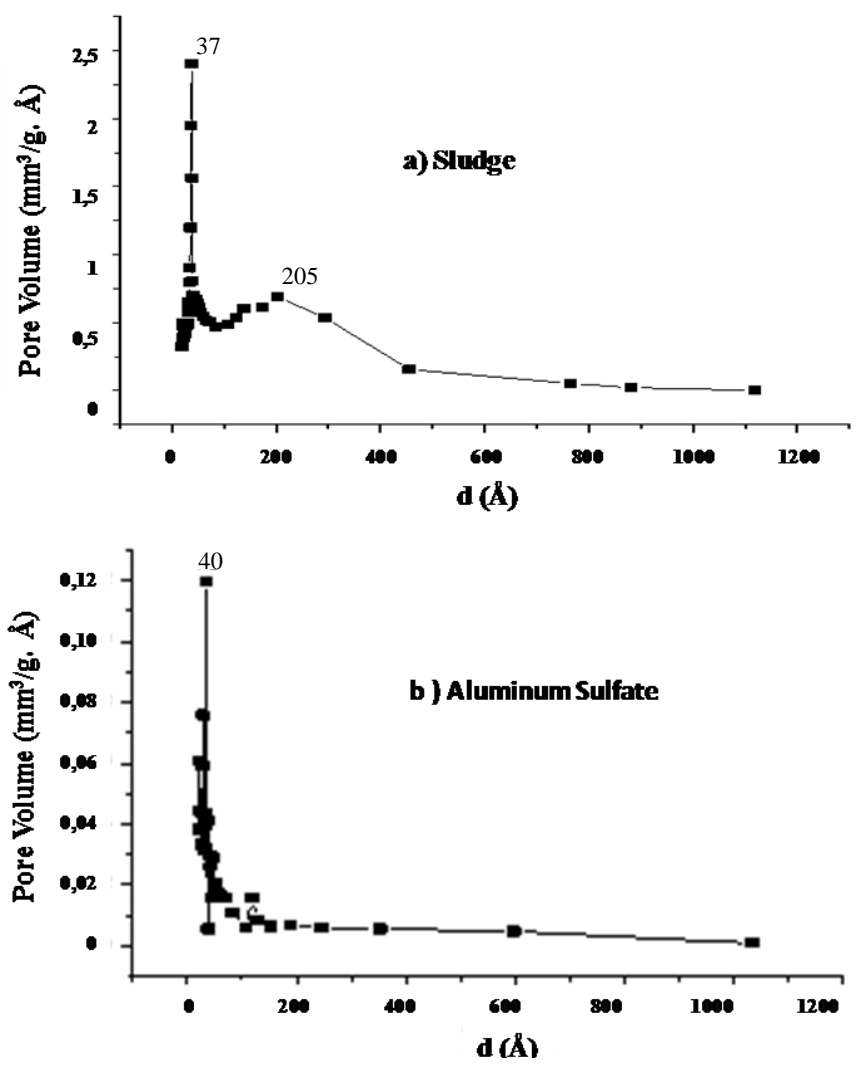

Figure 6. Pore Volume distribution of sludge (a) and aluminum sulfate (b) samples.

Table 7. Total porous volumes (V), specific surfaces (S), and pore diameter for sludge and aluminum sulfate determined from $\mathrm{N} 2$ adsorption/desorption isotherms.

\begin{tabular}{cccc}
\hline Solid & $\begin{array}{c}\text { Surface area } \\
\mathrm{S}\left(\mathrm{m}^{2} \cdot \mathrm{g}^{-1}\right)\end{array}$ & $\begin{array}{c}\text { Volume adsorbed } \\
\mathrm{V}\left(\mathrm{cm}^{3} \cdot \mathrm{g}^{-1}\right)\end{array}$ & $\begin{array}{c}\text { Pore diameter } \\
\mathrm{d}(\AA)\end{array}$ \\
\hline Sludge & 81 & 0.24 & 37 and 205 \\
Sulfates & 1.7 & 0.005 & 40 \\
\hline
\end{tabular}


Textural parameters measurements of sludge and aluminum sulfate are generally classified in the case of mesoporous solids. Nevertheless, that sludge exhibits a more porous structure: it presents higher specific surface area (S) and volume diameters of the pores $(\mathrm{V})$, than aluminum sulfate. To our knowledge, this is the first time that this method have been used to characterize the sludge produced in water treatment plants in Morocco, few data are available in the literature with which to compare our results.

\section{Conclusions}

The use of sludge as coagulant aid is very important not only for process economy through reducing the cost of treatment but also in the management of the sludge volume. Therefore, it is reasonable to consider this approach to be applied in the treatment plant for water with similar turbidity level. In this work, physicochemical and bacteriological characteristics of raw water from Bittit and Ribaa karstic springs and dried sludge produced at water treatment plant, after treatment of water were determined. The comparison between isotherms obtained with the two products reveals that their structure is mainly mesoporous with a relative heterogeneous pore distribution, observed in the case of the sludge. Nevertheless, that sludge exhibits a more porous structure: it presents higher specific surface area BET and volume diameters of the pores than aluminum sulfate.

Concluding remarks, an interesting perspective would be to classify the sludge produced in other water treatment plants of Morocco on the basis of its texture, in order to reuse it as a coagulant aid in turbid water treatment processes. This is an important work, which will require the comparison of the data acquired by different researchers involved in the reuse of sludge in karstic spring water treatment processes.

\section{Conflicts of Interest}

The authors declare no conflicts of interest regarding the publication of this paper.

\section{References}

[1] Chen, Z., Auler, A.S., Bakalowicz, M., Drew, D., et al. (2017) The World Karst Aquifer Mapping Project: Concept, Mapping Procedure and Map of Europe. Hydrogeology Journal, 25, 771-785. https://doi.org/10.1007/s10040-016-1519-3

[2] Miche, H., Saracco, G., Mayer, A., Qarqori, K., Rouai, M., Dekayir, A., Chalikakis, K. and Emblanch, C. (2018) Hydrochemical Constraints between the Karst Tabular Middle Atlas Causses and the Saïs Basin (Morocco): Implications of Groundwater Circulation. Hydrogeology Journal, 26, 71-87. https://doi.org/10.1007/s10040-017-1675-0

[3] Amraoui, F. (2005) Contribution to the Knowledge of Karstic Aquifers: Case of the Lias of the Saiis Plain and the Middle Atlas Moyen Causse (Morocco). PhD Thesis, Université Hassan II Ain Chock, Casablanca.

[4] Shen, Y.H. (2005) Treatment of Low Turbidity Water by Sweep Coagulation Using Bentonite. Journal of Chemical Technology \& Biotechnology, 80, 581-586. https://doi.org/10.1002/jctb.1244 
[5] Teh, C.Y. and Wu, T.Y. (2014) The Potential Use of Natural Coagulants and Flocculants in the Treatment of Urban Waters. Chemical Engineering Transactions, 39, 1603-1608.

[6] Edzwald, J. (1993) Coagulation in Drinking Water Treatment: Particles, Organics and Coagulants. Water Science \& Technology, 27, 21-35. https://doi.org/10.2166/wst.1993.0261

[7] Bourgeois, J.C., Walsh, M.E. and Gagnon, G.A. (2004) Treatment of Drinking Water Residuals: Comparing Sedimentation and Dissolved Air Flotation Performance with Optimal Cation Ratios. Water Research, 38, 1173-1182.

https://doi.org/10.1016/j.watres.2003.11.018

[8] Kyncl, M. (2008) Opportunities for Water Treatment Sludge Reuse. GeoScience Engineering, 54, 11-22.

[9] Amraoui, F., Razack, M. and Bouchaou, L. (2003) Turbidity Dynamics in Karstic Systems. Example of Ribaa and Bittit Springs in the Middle Atlas (Morocco). Hydrological Sciences Journal, 48, 971-984. https://doi.org/10.1623/hysj.48.6.971.51418

[10] Farhaoui, M., Hasnaoui, L. and Derraz, M. (2016) Optimization of Drinking Water Treatment Process by Modeling the Aluminum Sulfate Dose. British Journal of Applied Science \& Technology, 17, 1-14. https://doi.org/10.9734/BJAST/2016/26840

[11] Farhaoui, M. and Derraz, M. (2016) Review on Optimization of Drinking Water Treatment Process. Journal of Water Resource and Protection, 8, 777-786. https://doi.org/10.4236/jwarp.2016.88063

[12] El Mghari, T. (2008) Portée d'accréditation de la direction du contrôle de la qualité des eaux (mci/ca/al 05/2005) de l'ONEE, Branche Eau.

[13] Brunauer, S., Deming, L.S., Deming, W.S. and Teller, E. (1940) On a Theory of the Van der Walls Adsorption of Gases. Journal of the American Chemical Society, 62, 1723-1732. https://doi.org/10.1021/ja01864a025

[14] Farhaoui, M. and Derraz, M. (2016) Optimizing Coagulation Process by Using Sludge Produced in the Water Treatment Plant. Journal of Chemical and Pharmaceutical Research, 8, 749-756.

[15] Farhaoui, M. (2017) Optimization of Drinking Water Treatment Process, the Case of Meknes's Water Treatment Plant. Ph.D. Thesis, Faculty of Sciences, Moulay Ismail University, Meknes. https://doi.org/10.13140/rg.2.2.11020.10885 